\title{
Charging for stormwater in South Africa
}

\author{
L Fisher-Jeffes* and NP Armitage \\ 'Department of Civil Engineering, University of Cape Town, Private Bag X3, Rondebosch 7701, South Africa
}

\begin{abstract}
The social, economic and environmental impacts of poor water quality on South Africa's urban aquatic systems are increasingly being highlighted by the media. Improving the water quality in these systems will require catchment-wide strategies, including the monitoring and management of point and non-point source pollution collected in stormwater. Significant costs may be incurred; however, international experience suggests that these are outweighed by the benefits.

Municipalities across South Africa charge their citizens for potable water and sewerage. Stormwater management, however, is generally funded through municipal rates. Competition with other pressing needs frequently results in the stormwater departments being significantly under-funded - at times only receiving a tenth of what is required for water quantity management. Internationally, an increasing number of cities have introduced a direct charge for stormwater management in order to secure the funding required to manage stormwater and its associated water pollution, and to serve as a disincentive to polluting practices on the part of landowners. In order to ensure adequate funding for stormwater management in South Africa, municipalities need to consider charging for stormwater management either based on an Equivalent Residential Unit (ERU) or Residential Equivalent Factor (REF), combined with an appropriate discount scheme for on-site stormwater management. Preliminary indicative rates have been calculated for municipalities across South Africa using the Damage Avoidance Cost (DAC) approach. The results indicate that the amount that municipalities could and should charge varies widely, from ZAR30 (2010) to ZAR110 (2010) per residential unit per month, depending on climatic zone and level of treatment.
\end{abstract}

Keywords: stormwater management, damage avoidance cost, stormwater utilities

\section{INTRODUCTION}

The impact of poor water quality on South Africa's urban aquatic systems is increasingly being highlighted by the local media (Ndenze, 2011; eThekwini Municipality, 2011; SAPA, 2011; Oelofse, 2011; Helfrich, 2011; Tatler, 2011). Most reports focus on the failure of sewage systems (e.g. SAPA, 2011), due to the emotive nature of the pollution, and the ability to identify who is responsible due to the point source nature of sewage pollution. Stormwater pollution, on the other hand, is in general diffuse and therefore it is difficult to attribute responsibility. The Cities of Cape Town (CoCT, 2010), Johannesburg (CoJ, 2003) and Tshwane (CoT, 2002) all note in their State of the Environment Reports (SOER) that polluted stormwater is a significant contributor to the deteriorating water quality in their respective urban aquatic systems, as well as contributing to the failures of the sewage treatment works that become overloaded as a result of stormwater ingress into the foul sewer network. Improving the water quality in South Africa's urban aquatic systems will require catchment-wide strategies that consider the whole urban water cycle (UWC), including: water supply; sanitation; stormwater; and asset management. Appropriate management will require significant financial input in the short term, but it is important to recognise the ecosystem benefits that will result (TEEB, 2010). The focus of this paper is on how to raise finance for better stormwater management.

This paper was originally presented at the 2012 Water Institute of Southern Africa (WISA) Biennial Conference, Cape Town, 6-10 May 2012.

* To whom all correspondence should be addressed.

III +27 21 650-5317; e-mail: 1loyd.fisherjeffes@gmail.com
The UWC is currently managed in a fragmented manner in South Africa (Fisher-Jeffes et al., 2012). For example, in many of the larger cities, stormwater management is frequently the responsibility of the roads department. The poor integration of stormwater management with the rest of the UWC (Fisher-Jeffes et al., 2012) results in South African municipalities not having a holistic approach covering all water services. Stormwater management often ends up being inadequate - with those responsible for it operating with insufficient budgets due, in part, to institutional arrangements related to income generation for service provision. Stormwater is often managed as a potential flood hazard and disposed of as rapidly as possible. This approach focuses on managing quantity and ignores the management of quality.

Municipalities have a constitutional obligation to provide a safe, healthy environment while ensuring economic development and extending the provision of services in a progressive and sustainable manner (RSA, 1996). The management of stormwater is - partly owing to issues of underfunding - falling short of these aspirations. Municipal infrastructure in general in South Africa requires extensive re-investment in capital and maintenance expenditure: 'Extrapolated results suggest a current replacement cost [CRC] of ZAR723 billion for all municipal infrastructure under direct control of municipalities, and a depreciated replacement cost in the order of ZAR385 billion, which results in a weighted 53\% [Depreciated Replacement Cost] DRC/CRC ratio. This ratio ranges from as low as $44 \%$ for solid waste facilities to $58 \%$ for roads and stormwater' (Boshoff, 2009).

This underfunding of stormwater management is not unique to South Africa; however the situation is particularly bad in South Africa. In South Africa, most funding for stormwater management comes from general municipal rates unlike, for example, potable water and electricity for which 
municipalities have service charges (after making allowance for free basic services to the indigent). Competition with other pressing needs frequently leads to stormwater management being significantly under-funded - sometimes receiving only a tenth of what is required for stormwater quantity management alone (Fisher-Jeffes et al., 2012). This makes it impossible for municipalities to meet their obligations with respect to stormwater quality management - with consequent damage to the environment and loss in ecosystem benefits (Oelofse, 2011). Again South Africa is behind the rest of the world with numerous other governments already having established the legal frameworks and institutional capacity to charge service fees for stormwater management (e.g. Fitzroy, 2007; Campbell, 2010). Municipalities should be investing in stormwater management approaches in line with best international practice. Sustainable drainage systems (SuDS) - where stormwater is treated as close to the source as possible in as natural a manner as possible - is one approach that municipalities could be using to manage stormwater in a more holistic manner and gain the multiple benefits that conventional systems do not offer (Charlesworth et al., 2003). The SuDS approach is also increasingly becoming the accepted best practice for managing stormwater internationally (Marsalek and Chocat, 2002). Instead, in part as a result of financial constraints, municipalities are barely able to maintain their piped systems, resulting in the on-going degradation of the environment. Alternative financing models need to be considered for funding stormwater management - whether for conventional stormwater management or SuDS.

Internationally, an increasing number of cities have set up separate stormwater utilities (SU) and have begun charging the public directly for stormwater management services in order to secure the necessary funding to better manage stormwater and the associated water pollution (Honchell, 1986; Reese, 1996; Keeley, 2007; Chouli et al., 2007; Chouli and Deutsch, 2008; USEPA, 2009; Campbell, 2010; Campbell, 2011; Black \& Veatch, 2010; PWD, 2012). This fee can also be used as an incentive for good behaviour on the part of landowners through appropriate rebates/subsidies (Keeley, 2007). If South African municipalities are to address the deteriorating water quality trends noted in their respective SOER's (CoT, 2002; CoJ, 2003; CoCT, 2010), they need to properly finance and manage stormwater. Charging for stormwater, whether administered by the municipality or an independent stormwater utility, is 'not a way out of financial problems' (Honchell, 1986), but it offers a means of ensuring adequate resources for the effective management of storm drainage.

\section{STORMWATER MANAGEMENT FEES}

\section{Stormwater: a public service or 'polluters should pay'?}

Runoff quantity and quality are broadly the result of four factors: the rain regime, geomorphology, impermeable surfaces, and polluting urban activities. The argument underlying stormwater management as a public service revolves around the fact that the rain regime and geomorphology are not factors that can be managed, but may result in certain cities/regions with 'undesirable conditions' needing to charge more for the same level of service than others. This is likely to have the greatest impact on poorer communities, which in turn may result in a lower level of service being implemented in these areas. Additionally, runoff is generated from public spaces (e.g. roads) that are used by all and not easily assignable to individuals. This implies some sort of equitable sharing of the burden to ensure adequate financing for the whole system and thus proper protection of the environment (Chouli and Deutsch, 2008).

On the other hand, the 'polluter pays principle' is well established throughout the world. In the USA, the National Pollutant Discharge Elimination System (NPDES) holds municipalities liable for the quality of their runoff. This has forced municipalities to pay for pollution prevention, passing the costs onto ratepayers. Some municipalities, e.g. the City of Bloomington, have used the implementation of the NPDES as motivation for establishing a stormwater utility (SU). By assuming that many impermeable surfaces (new and existing) can be attributed to individual property owners, it is possible to apply the 'polluter pays principle' to individuals (Chouli and Deutsch, 2008). This is then used as an incentive scheme whereby property owners receive a rebate if they implement approved source-control technologies.

\section{Stormwater fees versus stormwater taxes}

The manner in which the stormwater charge is defined is of utmost importance; 'if made to look like a tax, legal troubles could follow' (Campbell, 2010). Experience in the USA indicates that a tax - meaning a sum of money demanded by a government for its support for specific services - is often challenged. Any stormwater charge must thus be seen as a reasonable payment for the provision and management of stormwater infrastructure (Campbell, 2011). This suggests that any money raised from fees should be spent on those who paid for the service. In South Africa, however, this is problematic as many cannot afford to pay. Determining who should pay, how the fees should be levied, and how the money should be utilised is likely to be challenging. As noted by Nascimento et al. (2005), stormwater services are public goods: 'This means that it is not possible to exclude someone from their benefit; when the service is offered, everyone is entitled to it and will necessarily consume it... its use must be available for all'. Stormwater services must be provided whether property owners can pay for the service or not. This implies some form of cross-subsidisation. It also means that a very important consideration should be the level of service to be provided as this will determine the cost. Furthermore, if the citizens of South Africa wish to protect their environment they will need to adopt best stormwater practice.

Ideally the stormwater management fee should be calculated based on the burden that stormwater runoff from each property is potentially placing on the environment and the consequential cost to the local authority to prevent damage. It is important to demonstrate this burden to property owners and show the likely benefits of good stormwater management in order to highlight that the stormwater fee is not an unfair, further burden. This will hopefully reassure property owners that they would be paying for the services received, hence the charge remaining a fee rather than a tax. Without cross-subsidisation, however, there will be limited improvement in stormwater management for some sectors of society - and a failure to address the stormwater problem in its entirety. The challenge then is finding solutions to manage the system within the limited funding, or alternatively finding a means of closing the funding gap created by those who cannot pay without unjustly charging those already paying stormwater fees.

\section{Stormwater utilities}

A public utility is variously described as 'a business enterprise, (or) a public-service corporation, performing an essential 


\begin{tabular}{|c|c|c|}
\hline \multicolumn{3}{|r|}{$\begin{array}{c}\text { TABLE } 1 \\
\text { Terms commonly used in the determination of stormwater fees }\end{array}$} \\
\hline No. & Term & Definition \\
\hline 1 & $\begin{array}{l}\text { ERU - Equivalent } \\
\text { Residential Unit }\end{array}$ & $\begin{array}{l}\text { The Equivalent Residential Unit (ERU) approach uses the average impervious area of a residential } \\
\text { property as a standard unit to determine the standard stormwater charge for residential properties of } \\
\text { a certain zoning category (e.g. single dwelling residential) in a SU's jurisdiction. All properties of that } \\
\text { zoning category are charged the same (Campbell, 2011). }\end{array}$ \\
\hline 2 & $\begin{array}{l}\text { REF - Residential } \\
\text { Equivalent Factor }\end{array}$ & $\begin{array}{l}\text { The Residential Equivalent Factor (REF) approach calculates the average volume of runoff for a chosen } \\
\text { storm event for properties with the same zoning status (e.g. single dwelling residential). All properties } \\
\text { of that zoning category are charged the same (Campbell, 2011). The difference with the ERU method is } \\
\text { that the REF method accounts for additional hydrological processes such as interception storage and } \\
\text { runoff from pervious areas. }\end{array}$ \\
\hline 3 & $\begin{array}{l}\text { Gross Property } \\
\text { Area }\end{array}$ & $\begin{array}{l}\text { A fee is levied upon the total (gross) area of the plot. The fee is set to recoup the expenses of managing } \\
\text { stormwater for the stormwater utility. This approach effectively assumes the whole property contributes } \\
\text { to the runoff or that all properties are equally developed (Campbell 2010). It is the least refined of the } \\
\text { approaches. }\end{array}$ \\
\hline 4 & $\begin{array}{l}\text { Distributed } \\
\text { Transportation } \\
\text { Alternative }\end{array}$ & $\begin{array}{l}\text { This approach considers the stormwater management of municipal roads and calculates the charge } \\
\text { based on estimated average road trip length of a specific user. In other words, this means that people } \\
\text { making more use of the road network pay higher stormwater fees. Added to the initial fee is a storm- } \\
\text { water management charge for residential properties which is generally based on impervious area } \\
\text { (Mariot, 2000). This is a very detailed and complicated approach. }\end{array}$ \\
\hline 5 & $\begin{array}{l}\text { Hydrologic } \\
\text { Alternative }\end{array}$ & $\begin{array}{l}\text { This charge is based on on-site characteristics: soil type, topography, impervious area, etc. (Mariot, } \\
\text { 2000). This approach requires detailed information on each plot. }\end{array}$ \\
\hline 6 & $\begin{array}{l}\text { Incentive / } \\
\text { Discount Scheme }\end{array}$ & $\begin{array}{l}\text { In order to encourage residents to take up on-site stormwater management an incentive scheme may be } \\
\text { built into the billing system to compensate those who are managing stormwater on-site. This is in line } \\
\text { with the principle of residents paying for their use of the stormwater system (Mariot, 2000). }\end{array}$ \\
\hline 7 & $\begin{array}{l}\text { Intensity of } \\
\text { Development (ID) }\end{array}$ & $\begin{array}{l}\text { The stormwater fee is based on the percentage of impervious area relative to the entire property size } \\
\text { (USEPA, 2009). }\end{array}$ \\
\hline
\end{tabular}

\begin{tabular}{|l|l|l|l|l|}
\hline \multicolumn{9}{|c|}{ TABLE 2 } \\
\hline Country & $\begin{array}{l}\text { Average } \\
\text { rate (per } \\
\text { month) }\end{array}$ & $\begin{array}{l}\text { Average rate } \\
\text { converted to } \\
\text { ZAR }\end{array}$ & $\begin{array}{l}\text { Rates adjusted: } \\
\text { Purchasing power } \\
\text { parity }\end{array}$ & Notes \\
\hline $\begin{array}{l}\text { USA } \\
\text { Average: } \\
\text { US\$4.19 }\end{array}$ & $\begin{array}{l}\text { ZAR8-160 } \\
\text { Average: } \\
\text { ZAR33 }\end{array}$ & $\begin{array}{l}\text { Range: } \\
\text { ZAR5- ZAR98 } \\
\text { Average: ZAR20 }\end{array}$ & $\begin{array}{l}\text { The size of the average residential property is unknown. There is a large } \\
\text { range in the fees charged in the USA, however when only those fees that } \\
\text { fully cover the service are considered the range narrows to US\$16-20 } \\
\text { (Black \& Veatch, 2010) }\end{array}$ \\
\hline Germany & $\begin{array}{l}€ 13.5 \\
(2003)\end{array}$ & $\begin{array}{l}\text { ZAR126 } \\
(2003)\end{array}$ & ZAR69 & For a $160 \mathrm{~m}^{2}$ residential unit (Chouli and Deutsch, 2008) \\
\hline Brazil & $\begin{array}{l}\mathrm{R} \$ 13 \\
(2009)\end{array}$ & $\begin{array}{l}\text { ZAR60 } \\
(2009)\end{array}$ & ZAR30 & $\begin{array}{l}\text { Estimate of what would be required for a } 160 \mathrm{~m}^{2} \text { residential unit (Tucci, } \\
2011)\end{array}$ \\
\hline
\end{tabular}

public service and regulated by the federal, state, or local government' (Dictionary.com, 2012). Stormwater utilities (SUs) are generally 'established to generate a dedicated source of funding for stormwater pollution prevention activities where users pay a fee based on land-use and contribution of runoff to the stormwater system' (NRDC, 2012). The issue of how the fees are charged is critical. In the USA, some cities charge fees through a separate utility that sends out a separate bill, while others include them as part of a general rates account. A survey of 70 utilities managing stormwater showed that: $50 \%$ were independent stormwater utilities; $33 \%$ of the utilities formed part of the local public works department; $11 \%$ were wastewater utilities which have extended their responsibilities to included stormwater management; and $9 \%$ had undefined arrangements (Black \& Veatch, 2010). In a sense it does not matter; the point is that an SU may be considered as any public service body that receives dedicated funding through stormwater fees for the provision of stormwater services.

\section{The determination of stormwater management fees}

Table 1 lists important terms frequently used in the determination of stormwater management charges.

Fees are most commonly levied on the basis of impervious area, i.e. the effective area draining to the stormwater system. Of the billing options available, implementing the ERU or REF combined with a discount scheme would appear to be the fairest and most appropriate for South Africa. The data required could be collected through building plans/GIS surveys and the fees charged would be based on the individual property characteristics - thereby reducing the number of complaints relating to unfair fees.

\section{Indicative international stormwater management fees}

Table 2 supplies an overview of what is being charged internationally. It is worth noting that the rates being charged do 


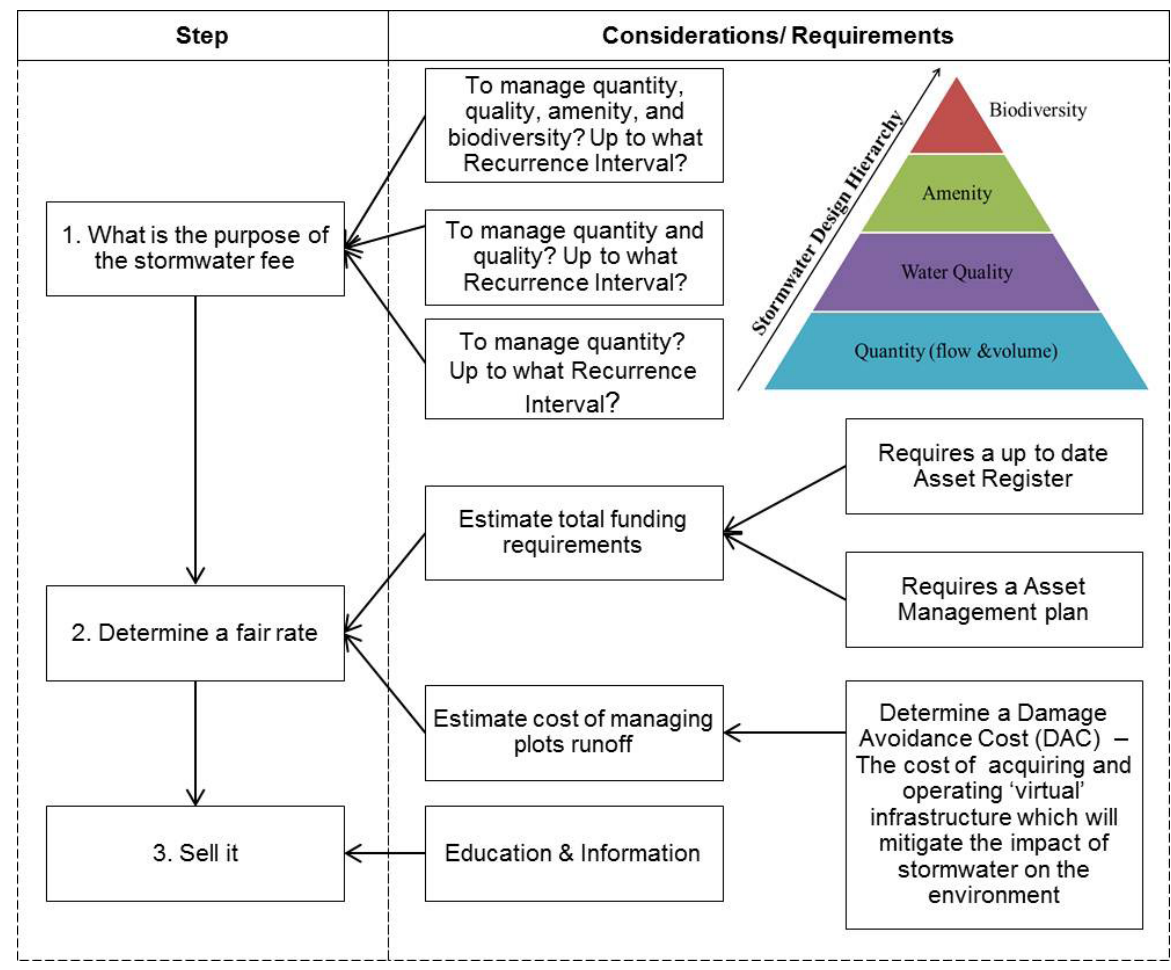

Figure 1

Procedure for determining stormwater utility fees not necessarily equate to sufficient funding for stormwater management in each city/country where they have been implemented.

\section{INTERNATIONAL EXPERIENCE WITH STORMWATER MANAGEMENT FEES}

Charging stormwater fees is not a new idea. It has been used in the USA since 1987 (Chouli and Deutsch, 2008). Germany, Sweden, Denmark, The Netherlands and the United Kingdom (Chouli et al., 2007) are examples of European countries implementing stormwater fees. Brazil, a developing country comparable in many ways to South Africa, is an example of a developing country considering charging for stormwater management. The following lessons are relevant to South Africa:

- Many SUs are successful. There are approximately 1200 1500 SUs charging residents for stormwater management in the USA alone (Campbell, 2011).

- The population served by these SUs varies from 33 to over 3 million (Campbell, 2010). Population size is irrelevant when charging a stormwater fee and thus it could be implemented in all municipalities in South Africa.

- A concern may be that implementing further fees may impact on new business investing in a municipal area. Campbell states that 'these claims are usually without foundation...a properly funded and managed stormwater utility can mean more parks and open space, less flooding, cleaner streams, and increased property values. A more desirable community improves the local economy' (Campbell, 2011).

- Stormwater fees may not supply sufficient funding (Black \& Veatch, 2010; Chouli and Deutsch, 2008). This is often the result of political interference in the setting of fees.

- In Germany, stormwater managers are concerned because their system operation and maintenance costs do not always reduce as properties disconnect from the network in an attempt to take advantage of discounts. This is due to the need to continue maintaining existing infrastructure and servicing plots that have not disconnected (Chouli and Deutsch, 2008).

- The higher the density of development, the more affordable stormwater management is on a city-wide basis. For example a block of flats has a smaller impermeable footprint per capita than the equivalent number of single storey houses accommodating the same number of people (Nascimento et al., 2005).

- Separate stormwater management fees do not necessarily increase the financial burden on individual landowners. Depending on how the fee is implemented, residents could see reduced total amounts paid as a consequence of a discount scheme (Campbell, 2011). On the other hand, in South Africa stormwater management currently receives minimal funding and thus the reduction in the general rates bill is likely to be negligible were stormwater management to become the responsibility of a self-funded utility. Meanwhile, the stormwater utility would probably be obliged to recover additional amounts to cross-subsidise services not otherwise paid for.

\section{DETERMINING STORMWATER FEES IN SOUTH AFRICA}

Figure 1 gives an overview of the major considerations necessary when establishing stormwater fees in South Africa.

\section{Define the purpose of the stormwater fees}

The purpose of the stormwater fees should be clearly defined. In South Africa this would include: securing sufficient funding for operations and maintenance; protecting the environment; developing modern stormwater drainage systems; or a combination of all of these. The stormwater hierarchy triangle (Fig. 1), demonstrates the order of priorities for managing stormwater; i.e., whether managing water quantity and quality alone, or whether 
also considering amenity and biodiversity. Furthermore, it is important to decide whether the fees will be sufficient to fund the administrative side or only construction and maintenance.

\section{Determine a fair rate}

Determining a fair rate is vital to successful implementation of billing for the management of stormwater. Parikh et al. (2005) note that 'To overcome the hydrologic and economic shortcomings of existing stormwater user fee/credit systems addressed above, the stormwater utility needs to incorporate more accurate hydrologic models, apply the price instrument to all landowners, and raise the price to reflect the marginal costs of reducing the desired level of runoff.' Once the purpose has been defined the fees should be levied in a manner that meets the following (SEAL) criteria (Honchell, 1986; Campbell 2011):

- Simple - the calculation of the fees should be easy to understand, easy to calculate and easy to implement.

- Equitable - the fees need to be seen to be fairly levied. This may be achieved by basing the fees on the burden that the property places on the stormwater management system. Through the use of remote sensing it should be possible to calculate each erf's burden relatively simply (Trauth, 2003). Incentives should be built in to motivate residents to implement on-site stormwater management thereby reducing the burden placed on the municipal infrastructure. By levying stormwater fees, municipal funding previously allocated for this purpose could be removed from the budget and will result in an adjustment of the municipal taxes.

- Adequate - the fees levied need to cover both the running expenses incurred by the utility as well as ensuring that the long-term management of the system is sustainable.

- Legal - the implementation of the fees needs to be legally sound. International experience has seen utilities being challenged in court. In South Africa where there is no pressure from the national government to establish such a utility, the move could well face a challenge. There is also a risk of it becoming a political issue which could derail the process if any legal flaws were to be found.

\section{Motivate the need for a stormwater service to consumers: 'sell it'}

The third and possibly most significant step is motivating to the community why the service is needed. The idea that it is a fee for a service offered as opposed to a tax must be stressed. There will be many vested interests that will attempt to prevent any attempt to levy stormwater fees. The public must be informed as to the need to charge for what seemed like a previously free service. This should include distributing information about: the damage stormwater does to the environment; the need for maintenance; the advantages of a well-maintained system; and the possibilities of reducing individual fees by implementing source-control measures on the property.

\section{ESTIMATING STORMWATER FEES FOR SOUTH AFRICA}

The calculation of stormwater fees in South Africa requires a simple method that accounts for the environmental costs of operating a stormwater system. One approach is through the use of the Damage Avoidance Cost (DAC). The DAC is the whole life-cycle cost of treating stormwater to acceptable standards through conventional means. It assumes the construction of regional virtual treatment works (they do not exist, but are simply a mechanism for cost estimation) - for which costs are readily determined. Essentially, the DAC is an estimate of the cost of stormwater management that has been externalised onto the environment in the form of ecosystem goods and services (EGS). The stormwater management fees are then determined to provide adequate funding to operate the virtual treatment works and, where possible, maintain amenity and biodiversity, on a regional basis. It is assumed that the alternative SuDS approach would have to be more economical than conventional methods before it would be implemented. Table 3 presents the current City of Cape Town treatment objectives for stormwater systems which can be used in the design of the virtual treatment works.

A tool, known as the DAC tool, was developed by the first author to calculate the Damage Avoidance Cost. Figure 2 presents the virtual treatment works assumed by the DAC tool to be the most cost-effective way of treating stormwater discharge from a conventional drainage system in order to meet the objectives described in Table 3. Computation of the DAC must be carried out carefully to ensure that at all times the 'least cost principle' is adhered to. Optimal performance of each unit process is thus assumed. The result is usually presented as a cost per impervious area.

\begin{tabular}{|l|l|l|}
\hline \multicolumn{2}{|c|}{ The City of Cape Town treatment objectives for stormwater } \\
systems (CSRM, 2009)
\end{tabular}

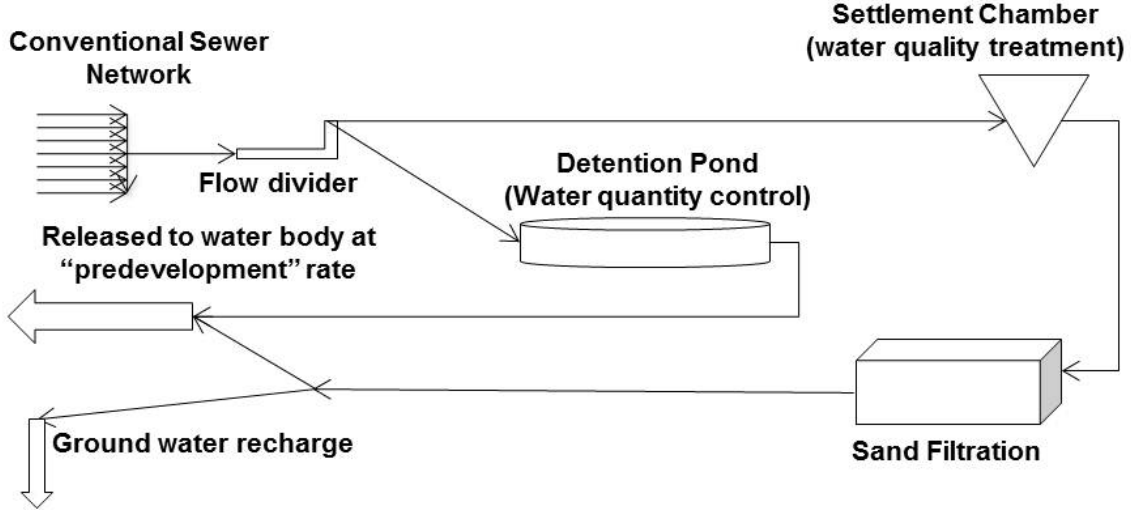

\section{Figure 2}

Schematic treatment train for virtual treatment works used to estimate the DAC 
The DAC does not include the cost of installing and maintaining the stormwater network conveying the runoff from source to the facility which must be added. The DAC, and a method for calculating the cost of managing the network, is detailed in Fisher-Jeffes and Armitage (2011).

\section{Stormwater fees for South Africa}

The DAC tool was used to calculate indicative rates for 3 South African municipalities. Table 4 provides a summary of the potential stormwater management fees for typical residential plots based on the assumptions of typical local conditions and by using the DAC approach. The costs (using 2010 figures) include the cost of purchasing land, as a treatment works would need to be situated somewhere. Since the cost of land varies widely within any city, a range of values is given. It is evident when Table 4 is compared with Table 2 that the fees are comparable with those charged internationally.

\begin{tabular}{|l|l|l|l|}
\hline \multicolumn{4}{|c|}{ TABLE 4 } \\
\hline \multicolumn{1}{|c|}{ Indicative stormwater fees for South Africa (2010 values) } \\
\hline City & $\begin{array}{l}\text { Monthly Stormwater Charge per residential unit } \\
\text { (160 } \text { m }^{2} \text { impervious area) }\end{array}$ \\
\cline { 2 - 4 } & $\begin{array}{l}\text { Cost of } \\
\text { treatment } \\
\text { constructing } \\
\text { and maintaining } \\
\text { stormwater } \\
\text { treatment } \\
\text { facilities (ZAR) }\end{array}$ & $\begin{array}{l}\text { Cost of } \\
\text { purchasing } \\
\text { land for } \\
\text { treatment } \\
\text { facility (ZAR) }\end{array}$ & $\begin{array}{l}\text { Total monthly } \\
\text { charge } \\
\text { for typical } \\
\text { residential } \\
\text { plot (ZAR) }\end{array}$ \\
\hline $\begin{array}{l}\text { City of Cape } \\
\text { Town }\end{array}$ & ZAR28 & ZAR20-40 & ZAR48-68 \\
\hline $\begin{array}{l}\text { City of } \\
\text { Tshwane }\end{array}$ & ZAR33 & ZAR27-54 & ZAR60-87 \\
\hline eThekwini & ZAR37 & ZAR36-72 & ZAR73-109 \\
\hline
\end{tabular}

\section{CONCLUSIONS}

Proper stormwater planning and management is of particular importance in South Africa where water, in all its forms, is a scarce resource under increasing stress. Three of South Africa's major metropolitan municipalities' State of the Environment Reports (CoT, 2002; CoJ, 2003; CoCT, 2010), have acknowledged the impacts that conventional stormwater management approaches are having on the environment. Improved management of stormwater in line with international best practice is necessary in order to: prevent further degradation; mitigate the damage already done to the environment; and avoid public health problems related to poor water quality. This will require dedicated funding. This paper shows how this can be achieved through the charging of stormwater management fees - in the order of ZAR30 to ZAR110 per residential unit per month (2010 figures), depending on climatic zone and level of treatment. It is vital that new approaches to funding stormwater management in South Africa are considered. A failure to properly manage stormwater - which requires adequate funding that is currently not available - will have significant impacts on the state of South Africa's urban water bodies in the future.

\section{REFERENCES}

BLACK \& VEATCH (2010) 2010 Stormwater Utility Survey, Black \& Veatch. URL: http://www.bv.com/Downloads/Resources/ Brochures/rsrc EMS 2010 StormwaterUtilitySurvey.pdf (Accessed 1 September 2011).
BOSHOFF L and CHILDS R (2009) A basis for estimating infrastructure renewal requirements in the South African municipal space, 31 August 2009. i@ Consulting, Pretoria. URL: http://iatconsulting. co.za/Publications (Accessed 1 September 2011).

CAMPBELL W (2010) The Western Kentucky University Stormwater Utility Survey 2010. Western Kentucky University, Bowling Green.

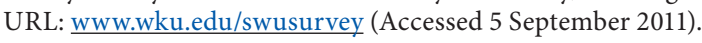

CAMPBELL W (2011) The Western Kentucky University Stormwater Utility Survey 2011. Western Kentucky University, Bowling Green. URL: www.wku.edu/swusurvey (Accessed 5 September 2011).

CHARLESWORTH SM, HARKER E and RICKARD S (2003) A review of sustainable drainage systems (SuDS): A soft option for hard drainage questions? Geography 88 (2) 99-107.

CHOULI E and DEUTSCH J (2008) Urban storm water management in Europe: What are the costs and who should pay? Proc. $11^{\text {th }}$ International Conference on Urban Drainage, 31 August - 5 September 2008, Edinburgh, Scotland. URL: http://web.sbe.hw.ac. uk/staffprofiles/bdgsa/11th International Conference on Urban Drainage CD/ICUD08/pdfs/162.pdf (Accessed 5 September 2011).

CHOULI E, AFTIASB E and DEUTSCHA J (2007) Applying storm water management in Greek cities: learning from the European experience. Desalination 210 (1-3) 61-68.

COCT (CITY OF CAPE TOWN) (2010) City of Cape Town State of the Environment Report 2009. URL: http://www.capetown.gov.za/en/ EnvironmentalResourceManagement/publications/Documents/ State_of_Environment_Report_2009_2010-08.pdf (Accessed 10 June 2011).

COJ (CITY OF JOHANNESBURG) (2003) State of the Environment Report 2003. Department of Development Planning, Transportation and Environment, Environmental Planning and Management Unit. City of Johannesburg, Johannesburg. URL: http://www.joburg-archive.co.za/2007/pdfs/enviroreport_apr2003. pdf (Accessed 19 January 2012).

CoT (CITY OF TSHWANE) (2002) State of the Environment Report of the City of Tshwane 2001-2002. Department of Housing, City Planning and Environmental Management, City of Tshwane, Pretoria.

CSRM (CATCHMENT, STORMWATER AND RIVER MANAGEMENT, CITY OF CAPE TOWN) (2009) Management of Urban Stormwater Impacts Policy. Catchment, Stormwater and River Management Branch, Roads and Stormwater Department, City of Cape Town, Cape Town

DICTIONARY.COM (2012) The American Heritage ${ }^{\star}$ Dictionary of the English Language ( $4^{\text {th }}$ edn.). Houghton Mifflin Company. URL: http://dictionary.reference.com (Accessed 17 January 2012).

ETHEKWINI MUNICIPALITY (2011) Press release: Possible Contamination of Rivers, Sea Water Near River Mouths and Storm Water Channels. URL: http://www.durban.gov.za/media publications/Press Releases/Pages/river-contanimation-.aspx (Accessed 23 May 2013)

FISHER-JEFFES LN and ARMITAGE NP (2011) A simple economic model for the comparison of SUDS and conventional drainage systems in South Africa. Proc. $12^{\text {th }}$ International Conference on Urban Drainage, 11-16 September 2011, Porto Alegre, Brazil.

FISHER-JEFFES L, CARDEN K, ARMITAGE NP, SPIEGEL A, WINTER K and ASHLEY R (2012) Challenges facing implementation of water sensitive urban design in South Africa [online]. In: WSUD 2012: Water sensitive urban design; Building the water sensitive community; 7th International Conference on Water Sensitive Urban Design, 21 - 23 February 2012, Melbourne Cricket Ground. Barton, A.C.T.: Engineers Australia, 2012: 902-909. URL: http:// search.informit.com.au/documentSummary; $\mathrm{dn}=829249994614282$ ;res=IELENG. ISBN: 9780858258952 (accessed 12 Jun 2013).

FITZROY R (2007) Charging ahead for stormwater - a local perspective stormwater management services charge in NSW local governments. In: Rainwater and Urban Design 2007. Engineers Australia, Barton, ACT. 253-258. ISBN: 1877040614.

HELFRICH K (2011) Municipalities rise to the Blue Flag challenge. URL: www.thenewage.co.za/39161-1008-53-local municipalities rise to the Blue Flag challenge (Accessed 10 January 2012).

HONCHELL CV (1986) Creating a storm drainage utility. APWA Reporter January 1986 10-11. 
KEELEY M (2007) Using individual parcel assessments to improve stormwater management. J. Am. Plann. Assoc. 73 (2) 149-160.

MARRIOT D (2000) Report to Council on Stormwater Management Charges (Portland, Oregon, USA) URL: http://www.portlandonline.com/bes/index.cfm? $=40874 \& c=46961$ (Accessed 6 September 2011).

MARSALEK J and CHOCAT B (2002) International Report: Stormwater. Water Sci. Technol. 46 (6-7) 1-17.

NASCIMENTO N, CANCADO V and CABRAL J (2005) Taxing for stormwater drainage systems. Water Sci. Technol. 52 (9) 251-258.

NDENZE B (2011) Project to clean up city rivers, Cape Times. URL: http://www.iol.co.za/capetimes/project-to-clean-up-city-riversgets-afloat-1.1161162 (Accessed 10 January 2012).

NRDC (NATURAL RESOURCES DEFENSE COUNCIL) (2012) Glossary, Natural Resources Defense Council. URL: http://www. nrdc.org/reference/glossary/a.asp (Accessed 23 January 2013).

OELOFSE J (2011) Knysna works towards clearing its estuary's waters. URL: http://www.cxpress.co.za/showArticle.asp?aid=7485 (Accessed 8 January 2012).

PAGIOLA S, VON RITTER K and BISHOP J (2004) Assessing the Economic Value of Ecosystem Conservation. Environment Department Paper No. 101. World Bank Environment Department, Washington.

PARIKH P, TAYLOR M, HOAGLAND T, THURSTON H and SHUSTER W (2005) Application of market mechanisms and incentives to reduce stormwater runoff. Environ. Sci. Pol. 8 (2) 133-144. DOI:10.1016/j.envsci.2005.01.002.

PWD (PHILADELPHIA WATER DEPARTMENT) (2012) How are charges calculated. Philadephia Water Department. URL: http:// www.phila.gov/water/Stormwater how.html (Accessed 19 January 2012).
REESE A (1996) Storm-Water Utility User Fee Credits. J. Water Resour Plann. Manage. 122 (1) 49-56. DOI: 10.1061/(ASCE)0733-9496.

RSA (REPUBLIC OF SOUTH AFRICA) (1996) Constitution of the Republic of South Africa. Act No. 108 of 1996. Government Gazette 17678, 18 December 1996.

SAPA (2011) Sewerage system flooded in eThekwini. URL: http:// www.iol.co.za/news/south-africa/kwazulu-natal/sewerage-systemflooded-in-ethekwini-1.1188956 (Accessed 5 December 2011).

SCHMIDT EJ and SCHULZE RE (1987) Flood Volume and Peak Discharge from small catchments in Southern Africa, based on the SCS technique. Agricultural Catchments Research Unit, Department of Agricultural Engineering, University of Natal, Pietermaritzburg, South Africa.

TATLER (2011) Friends keep Liesbeeck River pretty for 20 years. Tatler, 3 November 2011

TEEB (2011) The economics of ecosystems and biodiversity: Mainstreaming the economics of nature: a synthesis of the approach, conclusions and recommendations of TEEB. URL: http://www.teebweb.org (Accessed 11 December 2011).

TRAUTH K (2003) A role for remote sensing information in storm water planning and management. Clean Technol. Environ. Polic. 6 (4) 268-281. DOI:10.1007/s10098-003-0241-8.

TUCCI C (2011) Urban Drainage Institutional Development in Brazil. Key note address. $12^{\text {th }}$ International Conference on Urban Drainage, 11-16 September 2011, Porto Alegre, Brazil.

USEPA (UNITED STATES ENVIRONMENTAL PROTECTION AGENCY) (2009) Funding Stormwater Programs. URL: http://www.epa.gov/region1/npdes/stormwater/assets/pdfs/ FundingStormwater.pdf (Accessed 10 January 2012). 
http://dx.doi.org/10.4314/wsa.v39i3.13 Available on website http://www.wrc.org.za

ISSN 0378-4738 (Print) = Water SA Vol. 39 No 3 WISA 2012 Special Edition 2013 ISSN 1816-7950 (On-line) = Water SA Vol. 39 No 3 WISA 2012 Special Edition 2013 